\title{
Sosialisasi Penerapan Google Forms Sebagai Alat Penilaian Pembelajaran di SDN 117 Pekanbaru
}

\author{
Indah Muzdalifah*1, Dian Rianita², Elvira Asril $^{3}$ \\ 1,3Program Studi Sistem Informasi, Fakultas Ilmu Komputer, Universitas Lancang Kuning \\ 2Program Studi Ilmu Adiministrasi Negara, Fakultas Ilmu Komputer, Universitas Lancang Kuning \\ *e-mail: indah@unilak.ac.id1',dian@unilak.ac.id²,Elvira@unilak.ac.id³
}

\begin{abstract}
The corona virus pandemic indirectly has a very significant impact on aspects of human life, especially in the education aspect. Every role holder in education, both teachers, students, parents, must be ready to carry out the 4.0 revolution where learning is carried out online. The purpose of this community service activity is to provide socialization and share knowledge about the use of an application that can facilitate teachers in the assessment system or learning assessment which is usually carried out in class using paper replaced by using sophisticated applications that can be downloaded for free on the internet. The use of the application in question is Google form. This application aims to facilitate teachers in the assessment of learning evaluation. This activity made a significant contribution so that it was beneficial for partners in this activity, namely the teachers of SDN 117 Pekanbaru.
\end{abstract}

Keywords: Google form, assessment

\begin{abstract}
Abstrak
Pandemic virus corona secara tidak langsung memberikan dampak yang sangat significan terhadap aspek kehidupan manusia terutama pada aspek pendidikan. Setiap pemegang peranan dalam pendidikan baik guru siswa orang tua harus siap menjalankan revolusi 4.0 dimana pembelajaran dilakukan secara online. Tujuan kegiatan pengabdian masyarakat ini untuk memberikan sosialisasi dan berbagi ilmu mengenai penggunaan salah satu aplikasi yang dapat memudahkan para guru dalam system penilaian atau asseesment pembelajaran yang biasanya dilakukan dikelas dengan menggunakan kertas digantikan dengan menggunakan aplikasi canggih yang dapat diunduh secara gratis di internet. Penggunaan aplikasi yang dimaksud adalah google form. Aplikasi ini bertujuan untuk memudahkan guru dalam penilaian evaluasi pembelajaran. Kegiatan ini memberikan kontribusi yang berarti sehingga bermanfaat bagi mitra dalam kegiatan ini yaitu guru - guru SDN 117 Pekanbaru.
\end{abstract}

Kata kunci: Google form, penilaian

\section{PENDAHULUAN}

Corona virus atau covid 19 menjadi kata yang sangat familiar di dengar di seluruh dunia termasuk di Indonesia sejak awal bulan januari 2020. Dunia dikejutkan dengan ratusan bahkan ribuan korban jiwa dari sebuah virus yang berasal dari negeri tirai bambu China. Ratusan bahkan ribuan telah memakan korban jiwa. Sehingga padag tanggal 11 maret 2020 WHO menyatakan pandemi global. Berbagai negara diseluruh dunia memberlakukan lockdown guna menutup akses keluar masuk orang ke negara mereka masing - masing.

Virus yang mematikan ini tidak hanya menelan korban jiwa. Namun juga meluluh lantakkan seluruh aspek kehidupan manusia di berbagai belahan dunia. Baik aspek ekonomi, sosila budaya, agama dan pendidikan. Bidang pendidikan mendapatkan imbas dari wabah ini. Dengan diberlakukannya pembatasan sosial berskala besar, work from home, sosial distance dan fisikal distance menjadikan pembelajaran dikelas secara tatap muka ditiadakan. Pembelajaran dialihkan menjadi pembelajaran jarak jauh. Mau tak mau para guru, orang tua dan siswa harus mampu melaksanakan pembelajaran daring atau online.

Kegiatan pengabdian masyarakat kali ini adalah sengaja mengambil mitra guru - guru Sekolah Dasar yang juga masih canggung dalam penggunaan teknologi saat ini. Berdasarkan survey awal atau preliminary observation yang dilakukan pada tanggal 06 februari 2021 bahwa sebenarnya para guru - guru di SD ini sudah pernah mendapatkan pelatihan berupa penggunaan 
aplikasi google meet dan zoom cloud meeting dari dinas pendidikan kota Pekanbaru, namun guru yang di wawancarai oleh tim kegiatan pengabdian masyarakat ini mengaku masih belum memahami secara keseluruhan penggunaan aplikasi - aplikasi media berbasis online ini. Meskipun sosialisasi yang akan di adakan oleh tim ini nantinya hanya akan membahas sosialisasi yang merupakan bagian salah satu aplikasi media pembelajaran online, tim akan mencoba memberikan beberapa ilmu atau hal - hal yang terkait dengan penggunaan aplikasi media berbasis online ini nantinya, namun selain diberikan pelatihan tetap diperlukan juga kegiatan pendampingan yang berkelanjutan (Putri et al. 2018).

SDN 117 ini berlokasi sekitar $15 \mathrm{~km}$ dari Universitas Lancang kuning yang masih berada dalam satu kecamatan yaitu Rumbai. Sekolah ini terletak di jalan Pembina Pengambang Jaya Kelurahan Limbungan Kec. Rumbai Timur. Sekolah ini dipimpin oleh seorang kepala Sekolah yang bernama Hj. Sri Sulastri,M.Pd. Jumlah guru yang ada di sekolah ini sebanyak 15 orang terdiri dari 8 orang guru PNS dan 7 orang guru honorer, selain itu terdapat 1 orang kepala pustaka 1 orang tata usaha dan 1 orang pustakawan. Berikut ini data calon - calon partisipan yang akan mengikuti kegiatan pengabdian masyarakat nanti:

Berdasarkan hasil wawancara tim dengan beberapa orang guru di SD ini kebanyakan latar belakang orang tua para siswa di SD ini masih tergolong masyarakat ekonomi menengah kebawah. Hal ini berdampak terhadap kesiapan para orang tua di rumah dalam membimbing anak - anak mereka dirumah dalam pembelajaran online. Selain itu, ketika tim melakukan survey dan wawancara, informasi yang diterima sebelum terjadinya pancemic covid 19 ini bahwa guru masih memberikan ujian atau ulangan harian kepada siswa secara manual atau conventional. Misalnya memberikan tugas dan latihan melalui kertas yang mana kertas tersebut di bawa oleh guru untuk diperiksa kemudian setelah dinilai diberikan kembali kepada siswa yang mana hal seperti ini sangat tidak efektif karena kertas tersebut dapat rusak, robek, hilang bahkan mungkin menjadi sampah.

Berikut ini adalah beberapa kelemahan penerapan pemeberian tugas atau ujian dengan menggunakan kertas

a. Membutuhkan tenaga manusia yang lebih untuk mengetik soal, memperbanyak soal.

b. Membutuhkan sumber daya kertas dan tinta yang lebih banyak karena solah harus dicetak dan diperbanyak.

c. Meninggalkan residu yaitu kertas soal ujian maupun lembar jawaban yang sudah digunakan.

d. Membutuhkan ruang yang lebih untuk menyimpan arsip soal dan lembar jawaban, serta membutuhkan waktu yang lama saat arsip soal dan arsip lembar jawaban dibutukan kembali. (Suryana, 2008)

Google Form merupakan salah satu komponen layanan Google Docs. Untuk seorang akademisi, Google Form dapat digunakan untuk melakukan kuis online, 1070omput tentang efektivitas pengajaran, mengumpulkan jawaban pertanyaan terbuka dan sebagainya . Aplikasi ini sangat cocok. Fitur dari Google Form dapat dibagikan ke orang lain secara terbuka atau khusus kepada pemilik akun Google dengan pilihan aksebilitas, seperti : read only (hanya dapat membaca) atau editable (dapat mengedit dokumen). Formulir dapat dengan mudah diterbitkan di Web melalui url khusus yang dihasilkan oleh Google dan dapat disematkan di blog dan situs web Google Docs juga dapat menjadi alternative bagi orang - orang yang tidak memiliki dana untuk aplikasi berbayar menggunakan program gratis (Sianipar, 2019)

Sebelum menggunakan Google Form harus memiliki akun Google, yaitu dengan mendaftar di https://accounts.google.com/signup. Setelah memiliki akun Google maka kita akan bisa menggunakan berbagai produk Google yang dirilis secara gratis, seperti Gmail sebagai alat untuk berkomunikasi dengan email, Drive sebagai alat penyimpanan online, Youtube sebagai alat berbagi dan menyimpan video, site sebagai alat untuk membuat website sederhana, blogger sebagai alat untuk blog, Google Plus sebagai alat untuk sharing artikel dan lain sebagainya. 
Adapun beberapa fungsi Google Form untuk dunia pendidikan adalah sebagai berikut : (Sianipar, 2019)

1) Memberikan tugas latihan/ulangan online melalui laman website,

2) Mengumpulkan pendapat orang lain melalui laman website,

3) Mengumpulkan berbagai data mahasiswa/dosen melalui halaman website,

4) Membuat formulir pendaftaran online untuk sekolah,

5) Membagikan kuesioner kepada orang - orang secara online.

Aplikasi ini berbasis web maka setiap orang dapat memberikan tanggapan atau jawaban terhadap kuis ataupun kuesioner secara cepat dimanapun ia berada dengan menggunakan aplikasi internet di 1071omputer / laptop maupun melalui handphone. Karena itu, dengan menggunakan aplikasi ini maka seorang dosen atau pegawai tidak memerlukan kertas lagi untuk mencetak kuis atau kuesionernya. Waktu yang diperlukannya juga akan semakin hemat dalam membagikan, mengumpulkan kembali dan menganalisis hasil kuis dan angketnya. Dengan demikian, aplikasi ini sangat cocok digunakan untuk mengumpulkan pendapat sekelompok orang yang berjauhan dan sulit dikumpulkan, mengelola pendaftaran acara atau sekolah melalui halaman internet, mengumpulkan data - data, membuat kuis, dan banyak lagi. (Sianipar, 2019)

Sangat banyak ditemukan hasil - hasil penelitian yang menunjukkan keefektifan dan keefisienan penggunaan google form dalam mengumpulkan data maupun penilaian. Beberapa diantaranya seperti pemanfaatan google Spreadsheet sebagai media pembuatan dashboard oleh Indri Handayani, Herrafika Kusumahati. Kemudian penelitian penggunaan google form dalam pemberian NIM mahasiswa baru yang sebelumnya dilakukan secara konvensional melalui microsft exel dan microssoft word. Selanjutnya ada juga penelitian memudahkan registrasi pendaftaran test TOEFL melalui google form memudahkan staff administrasi menyimpan data bagi mahasiswa yang telah membayar dan mendaftar. (Handayani et al., 2018)

Google form merupakan salah satu aplikasi yang menampilkan template formulir atau lembar kerja yang dapat digunakan secara mandiri atau berkelompok guna memperoleh hasil yang di inginkan. Aplikasi ini dapat ditemukan dalam penyimpanan google drive dengan beberapa apliksi lainnya seperti Gooel Docs, Goole Sheet dan lainnya. Template google form sangat mudah digunakan dan dipelajari selain itu aplikasi ini menyediakan beberapa bahasa. Syarat dari penggunaan aplikasi google form ini hanya memiliki akun email google saja. (Tria, 2017). Pada template google form terdiri dari beberapa pilihan. Beriut ini tampilan google drive yang ada di layar.

Google Form adalah salah satu fitur layanan Google Docs. Aplikasi ini sangat mudah digunakan untuk mahasiswa, guru, dosen, pegawai kantor dan professional yang senang membuat quiz, form dan survey online. Fitur dari Google Form dapat di bagi ke orang-orang secara terbuka atau khusus kepada pemilik akun Google dengan pilihan aksesibilitas, seperti: read only (hanya dapat membaca) atau editable (dapat mengedit dokumen). Selain itu, Google docs juga dapat menjadi alternative bagi orang-orang yang tidak memiliki dana untuk membeli aplikasi berbayar untuk menggunakan program gratisan dibandingkan membajak program berbayar seperti Microsoft Office. (Batubara et al., 2016)

Google Forms merupakan salah satu aplikasi berupa template formulir (lembar kerja) yang dapat dimanfaatkan secara mandiri ataupun kolektif untuk tujuan mendapatkan informasi pengguna. Perkembangan TIK (Teknologi Informasi dan Komunikasi) menuntut perubahan dalam proses belajarmengajar, termasuk dalam pemberiantugas (penugasan) kemahasiswa (Muzdalifah, 2018) ; (Muzdaliifah, 2019); (Muzdalifah et al., 2020) ; (Zaenal 2011). Pada umumnya, pemberian tugas dilakukan dengan menggunakan media (kertas), namun dengan adanya Google Forms pemberian tugas dapat dilakukan secara online. Google Forms dapat digunakan sebagai salah satu media pembelajaran yang inovatif dan efektif (Iqbal et al., 2018) 


\section{METODE}

Kegiatan pengabdian masyarakat ini dilaksanakan pada tanggal 13 Agustus 2021 secara online menggunakan aplikasi zoom cloud meeting. Adapun guru yang hadir dalam kegiatan ini sebanyak 10 orang termasuk kepala sekolah. Guru tidak dapat hadir semua karena beberapa orang sedang dalam keadaan sakit. Namun demikian tidak mengurangi kelengkapan kegiatan pengabdian kepada masyarakat meskipun secara online. Dalam kegiatan pelaksanaan ini dibagi menjadi dua sesi, yang pertama sesi teori yang mana narasumber yang menyampaikan materi adalah ibu ketu Dra. Dian Rianita,M.A yang akan menyampaikan pemahaman tentang pentingnya evaluasi dalam pembelajaran. Kemudian akan disambung oleh anggota kegiatan yaitu ibu Elvira Asril,M.Kom yang memberikan pemahaman dan pengenalan tengang Google Form. Setelah itu akan dilanjutkan dengan langkah pratikum oleh ibu Indah Muzdalifah yaitu mempraktikkan pembuatan soal dalam google form untuk masing - masing guru. Tahap selanjutnya yaitu refleksi sebagai feedback kegiatan ini memberikan manfaat dan kontribusi terhadap mitra, makan tim menyiapkan angket yang berisi kepuasan dan penilaian terhadap kegiatan yang telah dilaksanakan dalam pengabdian ini.

\section{HASIL DAN PEMBAHASAN}

Ada 3 hal yang dapat dilaporkan dalam kegiatan pengabdian masyarakat ini. Yang pertama bahwa kegiatan ini dilakukan secara daring melalui zoom clod meeting sehingga tidak dapat bertemu secara tatap muka. Yang kedua, penyampaian materi tidak mengalami kesulitan dengan jaringan dan penyampaian suara lancar dan aman terkendali. Kehadiran dan pengisian angket serta pembuatan tugas untuk guru (bebrapa contoh soal dengan menggunakan google form dilaporkan secara daring melalui email salah satu anggota tim pengabdian)

Tabel 1. Hasil Angket penilaian mitra terhadap kegiatan pengabdian masyarakat

\begin{tabular}{llcccc}
\hline No & \multicolumn{1}{c}{ Heading } & $\begin{array}{c}\text { Sangat } \\
\text { setuju }\end{array}$ & setuju & $\begin{array}{c}\text { Kurang } \\
\text { setuju }\end{array}$ & $\begin{array}{c}\text { Tidak } \\
\text { setuju }\end{array}$ \\
\hline 1 & $\begin{array}{l}\text { Wawasan yang diberikan dalam kegiatan ini } \\
\text { baru bagi saya }\end{array}$ & 3 & 2 & 3 & 2 \\
2 & $\begin{array}{l}\text { Menurut saya kegiatan ini sangat } \\
\text { bermanfaat }\end{array}$ & 6 & 3 & 1 & 0 \\
3 & $\begin{array}{l}\text { Bagi saya kegiatan ini dapat menambah } \\
\text { wawasan saya dalam mengajar khususnya } \\
\text { dalam evaluasi pembelajaran }\end{array}$ & 5 & 4 & 0 & 1 \\
4 & $\begin{array}{l}\text { Dengan mengikuti kegiatan ini dapat } \\
\text { menjadi referensi bagi saya dalam evaluasi } \\
\text { pembelajaran dikelas }\end{array}$ & 5 & 3 & 2 & 0 \\
5 & $\begin{array}{l}\text { Kegiatan ini merupakan bagian } \\
\text { pengoptimalisasian teknologi dalam } \\
\text { pembelajaran di kelas }\end{array}$ & 7 & 0 & 2 & 1 \\
6 & $\begin{array}{l}\text { Penggunaan aplikasi ini memberikan } \\
\text { dampak positif paperless (pengurangan } \\
\text { kertas) dalam kegiatan pembelajaran }\end{array}$ & 7 & 3 & 0 & 0 \\
7 & $\begin{array}{l}\text { Kegiatan ini memberikan kontribusi yang } \\
\text { bagus dalam kegiatan pembelajaran online } \\
\text { agar lebih efisien dan praktis }\end{array}$ & 6 & 4 & 0 & 0 \\
$\begin{array}{l}\text { Kegiatan ini memberikan dampak positif } \\
\text { dalam penggunaan media pembelajaran } \\
\text { berbasis teknologi } \\
\text { Dengan mengikuti kegiatan ini saya akan } \\
\text { mencoba menerapkannya dalam }\end{array}$ & 5 & 4 & 1 & 0 \\
\hline
\end{tabular}




\begin{tabular}{lllll}
\hline pembelajaran dikelas saya & 3 & 1 & 1 \\
$\begin{array}{l}\text { Dengan mengikuti kegiatan ini saya akan } \\
\text { mencoba mensosialisaikannya kepada } \\
\text { orang tua dirumah untuk dapat membantu } \\
\text { anak didik saya dalam penerapan aplikasi } \\
\text { google form }\end{array}$ & & & & \\
$\begin{array}{l}\text { Penggunaan aplikasi ini sangat praktis dan } \\
\text { efisien sehingga dapat menghemat waktu } \\
\text { dalam penilaian evaluasi pembelajaran }\end{array}$ & 6 & 3 & 1 & 0
\end{tabular}

\section{KESIMPULAN}

Saat mengalami masa pandemic ini menjadikan guru dan peserta didik menggunakan technology secara perlahan. Ada banyak permasalahan terkait dengan pembelajaran daring atau online. Namun ditengah keterbatasan itu apabila disikapi dengan positif akan menjadikan sesuatu yang bermanfaat. Misalnya adalah dengan pemanfaatan technology ditengah pandemic corona, guru dapat memanfaaatkan aplikasi google form dalam melakukan penilian tugas atau Ujian peserta didik. Melalui kegiatan pengabdian masyarakat ini dengan mengambil subjek atau mitra guru - guru di SD 117 Pekanbaru ditemukan dari hasil angket bahwa penggunaan Google form sebagai salah satu alternative dalam penilaian atau pemberian tugas dalam kegiatan pembelajaran sangat bermanfaat dan dapat membantu guru dalam penilaian.

\section{DAFTAR PUSTAKA}

Batubara, H. H., Islam, U., Mab, K., Adhyaksa, J., \& Banjarmasin, N. (2016). Penggunaan Google Form Sebagai Alat Penilaian Kinerja Dosen Di Prodi Pgmi Uniska Muhammad Arsyad Al Banjari. Al-Bidayah: Jurnal Pendidikan Dasar Islam, 8(1).

Handayani, I., Aini, Q., Cholisoh, N., \& Agustina, I. I. (2018). Pemanfaatan Google Form Sebagai Pendaftaran TOEFL ( Test of English as a Foreign Language ) secara Online. Jurnal TEKNOINFO, 12(2), 55-59.

Iqbal, M., Amal, B. K., \& Rumapea, M. E. (2018). Penggunaan Google Forms Sebagai Media Pemberian Tugas Mata Kuliah Pengantar Ilmu Sosial. Jurnal Pendidikan Ilmu-Ilmu Sosial, $10(1), 120-127$.

Muzdalifah, I. (2018). Proceedings of the Sixth International Conference on English Language and Teaching. Proceedings of the Sixth International Conference, 2011, 96-107.

Muzdalifah, I., Asrli, E., \& Handayani, S. (2020). Moral Value in Serial Cartoon Upin and Ipin English Version. ELT Lectura: Studies and Perspectives in English Language Teaching, 7(August).

Muzdaliifah, I. (2019). Sosialisasi Penggunaan Media Pembelajaran Scrabble Online Berbasis Android Untuk Guru- Guru Bahasa Inggris Sd It Al Birru Pekanbaru. Dinamisia: Jurnal Pengabdian Kepada Masyarakat, 3(1), 94-99. https://doi.org/10.31849/dinamisia.v3i1.2197

Putri, L. D., Repi, \& Fitridawati Soehardi. (2018). Pemberdayaan Mahasiswa Fakultas Teknik Dengan Program Kreatifitas Mahasiswa (PKM).Dinamisia : Jurnal Pengabdian Kepada Masyarakat, 2(2), 315-321.

Sianipar, A. Z. (2019). Penggunaan Google Form Sebagai Alat Penilaian Kepuasan Pelayanan mahasiswa. Journal of Information System,Applied,Management, Accounting and Research, 3(1), 16-22. http://journal.stmikjayakarta.ac.id/index.php/jisamar/article/view/72/67

Suryana, O. (2008). Google form Tutorial (Issue May).

Tria, M. (2017). Google Form Sebagai Alternatif Pembuatan Latihan Soal Evaluasi. The 6th University Research Colloqium 2017, 183-188.

Zaenal, A. (2011 ). BukuPintar Google. Penerbit Media Kita. Jakarta 